\title{
SISTEM KEWARISAN DALAM PERSPEKTIF HUKUM ISLAM DAN AJARAN AGAMA BUDHA
}

\author{
Humphrey Sarwono Witjaksono \\ Sekolah Dasar Bina Budi Mulia \\ Jalan Ade Irma Suryani Nomor 8 Kota Malang \\ Email: humpreymkngmail.com
}

\begin{abstract}
Abstrak
Dalam sistem pembagian waris baik menurut Agama Budha maupun Agama Islam masih banyak menggunakan hukum adat atau hukum yang berlaku di masyarakat. meskipun banyak pilihan atau alternatif hukum dalam pembagian waris yang dapat digunakan antara lain, dalam Islam menggunakan 1) hukum adat 2) hukum faroid/hukum Islam 3) KHI dan 4) menggunakan KUH Perdata sedangkan dalam AjaranBudha hukum yang di gunakan dalam pembagian waris adalah Hukum adat dan KUH Perdata. Sedangkan yang menerima warisan dalam Agama Islam semuanya ahli waris bisa menerima asalkan tidak terhalang (alasan tidak bisa menerima waris) sedangkan dalam Agama Budha tidak semua ahli waris karena jika dalam keluarga tersebut (ahli waris) ada yang memutuskan untuk menjadi samanera atau samaneri dan bhikku maka secara otomatis dia tidak akan bisa menerima warisan.
\end{abstract}

Kata kunci: pembagian waris, agama Budha dan agama Islam

\section{Abstract}

In the system of inheritance distribution both according to Buddhism and Islamic Religion still use many customary laws or laws that apply in the community. although many legal choices or alternatives in the distribution of inheritance can be used, among others, in Islam using 1) customary law 2) faroid law/Islamic law 3) KHI and 4) using the Civil Code while in the Buddhist Teachings the law used in the distribution of inheritance is Customary law and the Civil Code. While those who receive inheritance in the Islamic Religion all heirs can accept as long as they are not obstructed (reason can not accept inheritance) while in Buddhism not all heirs because if in the family (heirs) someone decides to become samanera or samaneri and bhikku then automatically he will not be able to receive inheritance.. Keywords: distribution of inheritance, Buddhism and Islam 


\section{PENDAHULUAN}

Agama merupakan suatu hubungan yang tetap antara diri manusia dengan suatukekuatan yang berada diluar diri manusia yang bersifat suci (Tuhannya), dalam Agana Islam disebut Allah SWT. Agamajuga merupakan kepercayaan dan cara hidup yang mengandung faktor- faktor percayakepada adanya Tuhan, sebagai segala sumber hukum dan nilai-nilai kehidupan manusia.

Vihara sebagai tempat beribadah umat Buddha yang memiliki peran sangat penting didalam meningkatkan kesadaran nurani umat manusia, agar setiaptujuan, pikiran dan tindakannya selalu selaras dengan hati nuraninya, dan ini merupakan sebagian dari sumber energi Tuhan Yang Maha Esa.Sang Buddha menetapkan rumusan tersebut bukan hanya bagi mereka yang akan ditahbiskan menjadi samanera dan bhikkhu, tetapi juga bagi umat awam (pe-keluarga). Setiap orangyang memeluk Agama Buddha, baik ia seorang awam ataupun seorang bhikkhu, menyatakan keyakinannya dengan kata-kata rumusan Tisarana tersebut. Dan tempat ibadah dalam Agama Islam adalah Masjid yang merupakan tempat kita mengadu dan meyerahkan diri pada yang menciptakannya (Allah)

Sang Buddha sebenarnya menggolongkan 'harapan kematian' ini sebagai kelompok ketiga dari tiga jenis kemelekatan sebagai berikut:

1. Selain hasratuntuk kenikmatan duniawi yang kita temukan pada KebenaranMulia,

2. Kedua dan hasrat untuk menjadi (bhavatanha) dan

3. Hasrat untuk tidak menjadi (vibhavatanha).

Definisi kematian dalam ajaran Buddha. Menurut YM. Nyanatiloka, kematian biasanya disebut "lenyapnya indera vital terbatas pada satu kehidupan tunggal, dan bersamaan dengan fisik kesadaran proses kehidupan yang umumnya disebut "manusia, binatang, kepribadian, ego", dan seterusnya.

Dengan kata lainsesungguhnya kematian adalah peleburan dan pelenyapan dari setiap kombinasi mental fisik sesaat yang terjadi berulangkali, dan karenanya terjadi pada setiap saat. Secara umum semua tradisi Buddhisme menyepakati bahwa kematian dalam Ajaran Buddha tidak ditentukan semata-mata oleh faktor fisik. Akan tetapi faktor batin yang mencakup kesadaran dianggap berperan sebagai fakor utama kematian menurut pengertian Buddhis. Jadi, definisi kematian yang diterimaoleh cendekiawan Buddhis umumnya adalah ketika kesadarandalam seseorang telah padam. ${ }^{1}$

Kematian dalam Agama Budha, mengandung arti manusia akan di

${ }^{1}$ M. O'C. Walshe Willy Liu Ajaran Buddha Dan Kematian ,Cetakan Pertama, (Yokyakarta: Vidyāsenā Production, 2010,) hal 30. 
lahirkan kembali yang disebut dengan istilah "reinkarnasi" dan "kelahiran lagi". Kata "reinkarnasi" merupakan istilah yang digunakan oleh mereka yang percaya bahwa suatu entitas nyata (sebuah "jiwa") ada, dan berpindah dari satu kehidupan kepada kehidupan selanjutnya, menempati tubuh yang berganti-ganti. Secara harfiah, hal ini mestinya hanya diterapkan pada manifestasi dalam tubuh"daging" ( $f i s i k$ ), meskipun sudah umum diterapkan pada keadaan tubuh pula. Dalam artian bahwa setiap orang yang mati hanya jasatnya saja sedangkan rohnya akan hidup kembali di alamnya jadi manusia itu bukan mati akan tetapi berpindah dari alam dunia ke alam roh. Sedangkan kata "kelahiran lagi" menunjukkan pandangan ajaran Buddha bahwa meski ini yang kelihatannya terjadi, proses yang sebenarnya adalah sepenuhnya impersonal. Karenanya apa yang dalam kebenaran relatif muncul (dapat dialami oleh beberapa mahluk) sebagai reinkarnasi, adalah kebenaran mutlak dari kelahiran lagi.

Begitu juga dengan Ajaran Agama Islam, bahwa dengan kematian akan menyebabkan suatu kewarisan bagi ahli warisnya. Asalkan tidak ada penghalang dalam mewaris. Hal ini terdapat dalam Pasal 171 huruf (c) pada Kompilasi Hukum Islam (KHI) menyatakan bahwa ahli waris adalah orang yang pada saat meninggal dunia mempunyai hubungan darah atauhubungan perkawinan dengan pewaris, beragamaIslam dan tidak terhalang karena hukum untuk menjadi ahli waris.

Ketentuan dalam KHI memang tidak dinyatakan perbedaan Agamasebagai penghalang untuk dapat mewarisi, namun Pasal 171 huruf (c) KHI tersebut menyatakan bahwa pewaris dan ahli waris harus dalam keadaan beragama Islam diantara keduanya, apabila salah satunya tidak beragama Islam, maka diantara keduanya tidak dapat saling mewarisi.

Dari uraian di atas maka akan timbul suatu pertanyaan apakah ada perbedaan kewarisan menurut agama Budha dan agama Islam, oleh sebab itu yang menjadi rumusan masalah dalam penulisan ini adalah sebagai berikut: 1) Bagaimana kedudukan ahli waris non muslim (Agama Budha) terhadap harta warisan pewaris ditinjau dari ajaran agama Budha dan hukum Islam, dan 2) Bagaimana sistem dan sumber hukum kewarisan menurut ajaran agama Budha dan menurut hukum Islam.

\section{METODE PENELITIAN}

Penelitian merupakan suatu sarana pokok pengembangan ilmu pengetahuan maupun teknologi, hal ini karena penelitian bertujuan untuk mengungkapkan kebenaran secara sistematik, metodelogis dan konsisten. Melalui proses penelitian tersebut diadakan analisa dan kontruksi terhadap 
data yang telah dikumpulkan dan diolah. ${ }^{2}$ Sedangkan menurut Sutrisno Hadi penelitian atau reserch adalah usaha untuk menemukan, mengembangkan dan menguji kebenaran suatu pengetahuan, usaha dimana dilakukan dengan menggunakan metode-metode ilmiah. ${ }^{3}$ Dalam penelitian ini menggunakan jenis penelitian yuridis sosiologis dengan pendekatan yuridis antropologis, Jenis data yang digunakan dalam penelitian ini adalah jenis data primer dan sekunder. Dalam penelitian ini penulis menggunakan teknik analisis deskriptif kualitatif.

\section{PEMBAHASAN}

Definisi hukum kewarisan dalam Kitab Undang-Undang Hukum Perdata tidak dimuat secara tegas dalam buku Ke II BW, akan tetapidi dalam pasal $830 \mathrm{KUH}$ Perdata menyebutkan bahwa pewarisan hanya berlangsung karena kematian. Jadi harta peninggalan atau warisan baru terbukakalau si pewaris sudah meninggal dunia dan si ahli waris masih hidup saat warisan terbuka. Dari pasal tersebut mengadung arti bahwa kalau ada kematian pasti akan menimbulkan kewarisan. Menurut Vollmar berpendapat bahwa Hukum waris adalah perpindahan dari sebuah harta kekayaan seutuhnya, jadi keseluruhan hak-hak dan kewajiban-kewajiban, dari orang yang mewariskan kepada warisnya ${ }^{4}$.

Pengertian kewarisan dalam ajaran agama Budha tidak di atur secara tegas tentang kewarisan, dalam ajaran Budha, pengertian kewarisan bukan dalam harta benda atau benda-benda keduawian akan tetapi pengertian kewarisan dalam dhamma (kebaikan). Seperti yang diterangkan dalam buku Majjima Nikaya "Demikianlah yang Kudengar". Pada suatu ketika Sang Bhagavā sedang menetap di Sāvatthī di Hutan Jeta, Taman Anāthapiṇ̣ika. Di sana Beliau memanggil para bhikkhu: Parabhikkhu."Yang Mulia," mereka menjawab. Sang Bhagavā berkata sebagai berikut:"Para bhikkhu, jadilah pewarisKu dalam Dhamma, bukanpewarisKu dalam benda-benda materi.

Hukum kewarisan Islam dalam beberapa literatur disebut jugadengan faraid atau mawaris, adalah hukum tentang peralihan harta ataupembagian harta peninggalan dari keluarga muslim yang meninggaldunia. ${ }^{5}$ Dengan kata lain bahwa pewarisan dalam Agama Islam harus didahului dengan kematian

${ }^{2}$ Soerjono Soekanto dan Sri Mamuji, Penelitian Hukum Normatif Suatu Tinjauan Singkat, Jakarta, RajaGrafindo Persada, 2003, hal 1.

${ }^{3}$ Sutrisno Hadi, "Metodologi Researh Jilid 1 ", Yogyakarta, Andi, 2000, hal 4.

${ }^{4}$ Vollmar, Pengantar Studi Hukum Perdata Jilid I, diterjemahkan oleh I.S.Adiwimarta, (Jakarta: PT.Rajawali Pers,1989), hal. 373.

${ }^{5}$ Moh. Muhibbin, Hukum Kewarisan Islam sebagai Pembaruan Hukum Positif di Indonesia, (Jakarta: Sinar Grafika, 2009), hal 5. 
baru akan timbul suatu kewarisan dan pembagiannya menggunakan ilmu faraid atau aturan yang terdapat dalam KHI yang berlandaskan pada AlQur'andan Sunnah Nabi, peralihan kepemilikan harta kepada yang berhakmendapatkannya sesuai dengan bagiannya masing-masing, dilakukan setelah pemilik harta itu meninggal dunia, ketentuan ini diyakini dandiakui serta bersifat mengikat bagi semua umat Islam. Adapun dasarhukum kewarisan dalam Al-Qur'an adalah QS. An-Nisa' ayat 7 - 14, 33,176, dan QS. Al-Anfal ayat 75.Adapun sumber-sumber hukum warisan Islam adalah Pertama Al-Qur'an, Kedua Sunnah Rasulullah SAW, dan Ketiga ialah ijtihad para ahli hukum Islam. Dasar penggunaan ketiga sumber hukum warisan Islam itu pertama dalam Al-Qur'an: (4) surat An-Nisa' ayat 59:

"Hai orang-orang yang beriman, taatilah Allah dan taatilah Rasul (Nya), dan ulil amri di antara kamu. Kemudian jika kamu berlainan pendapat tentang sesuatu, Maka kembalikanlah ia kepada Allah (Al Quran) dan Rasul (Sunnahnya), jika kamu benar-benar beriman kepada Allah dan hari kemudian. yang demikian itu lebih utama (bagimu) dan lebih baik akibatnya"

\section{Kedudukan Ahli Wsaris Non Muslim (Agama Budha) Terhadap Harta Warisan PewarisDitinjau Dari Hukum Islam.}

AgamaIslam merupakan mayoritas Agama yang dianut oleh warga Negara Indonesia, maka sistem hukum kewarisan Islam menjadi salah satu sistem hukum yang berlaku di Indonesia. Sistem hukum warisan Islam sebagai bagian dari sistem syari'at merupakan dalam aspek sistem hukum mu'amalah atau juga dalam lingkungan hukum perdata.

Di dalam AjaranIslam hukum warisan ini tidak dapat dipisahkan dengan hukum Islam dan ibadah. Karenanya dalam penyusunan kaidahkaidah hukum warisan harus berdasarkan sumber-sumber hukum Islamdan hukum-hukum Islam yang lainnya. Kalau kita analisis dari pendapat Suparman dan Yusuf Somawinata dalam karangan bukunya yang berjudul "Fiqih Mawaris" sangalah jelas bahwa kedudukan ahli waris dan pembagian waris dalam AgamaIslam harus sesuai dengan hukum yang berlaku, dari pendapat belaiu ada tiga pilihan atau landasan yang menentukan pembagian kewarisan dalam menentukan kedudukan seorang ahli waris yaitu : 1) Pembagian waris yang memakai hukum yang berlaku atau ijtihad para ulama', 2) KUH Perdata Buku ke II dan yang ke 3) Hukum waris yang terdapat dalam hukum waris Islam, yaitu ketentuan hukum waris dalam Fiqih Islam, yang disebut Mawaris atau ilmu Faraidh serta hukum adat, akan tetapi dengan catatan, bahwa menentukan kedudukan waris menggunakan hukum adat haruslah ada kesepakatan antara semua ahli warissebelum menentukan kedudukan ahli waris. Dari pilihan tersebut 
kebanyakan orang muslim di Indonesia memakai landasan hukum dalam menentukan kedudukan seseorang dalam waris yaitu menggunakan Faraid dan menggunakan hukum adat istiadat yang berlaku, akan tetapi tidak meninggalkan syariat Islam yang berlaku. Kewarisan yang menggunakan hukum adat harus ada kesepakatan antara ahli waris terlebih dahulu agar tidak terjadi sengketa dikemudian hari.

Dengan demikian penulis dapat menarik suatu kesimpulan bahwa kedudukan ahli waris dalam AgamaIslam harus berpedoman pada Al-Quran dan As-Sunnah Nabi dan selain itu juga harus juga di-imbangi dengan Idjtihat para ulama' dalam menentukan kedudukan kewarisan serta pembagian kewarisan.

Dalam Islam untuk menetukan kedudukan dan seberapa yang di dapat dan siapa yang berhak kalau kita analisis dari Asas-asas kewarisan hukum Islam akan lebih jelas. ${ }^{6}$

1. Asas Ijbariialah pengalihan harta dari seseorangyang meninggal dunia kepada ahli warisnya berlakudengan sendirinya menurut ketetapan Allah. Tanpadigantungkan kepada kehendak pewaris dan ahliwarisnya. Asas ini berlandaskan pada Al-Qur'an surat An-Nisa' ayat 7

2. Asas Bilateraldalamhukum kewarisan Islam adalah seseorang menerimahak kewarisan dari kedua belah pihak kerabat, yaitudari garis keturunan perempuan maupun keturunan laki-laki. Untuk lebih jelasnya asas bilateral in dapat dilihat dalam surah an-Nisa ayat:7, dan 11. Dalam ayat7 dijelaskan dikemukakan bahwa seorang laki-laki berhak memperoleh warisan dari pihak ayahnya maupun ibunya. Begitu juga dengan perempuan mendapat warisan dari kedua belah pihak orang tuanya.Ayat ini merupakan dasar bagi kewarisan bilateralselanjutnya di pertegas dalam surah An-Nisa 11

3. Asas Individual adalah, setiap ahli waris (secara individu) berhak atas bagian yang didapatkan tanpa terikat kepada ahli waris lainya.Dengan demikian bagian yang diperoleh oleh ahli waris secara individu berhak mendapatkan semua harta yang telah menjadi bagianya. Ketentuan ini dapat dijumpai dalam ketentuan Al-quran surat an-Nisa ayat 7 yang secara garis besar menjelaskan bahwa anak laki-laki maupun perempuan berhak menerima warisan dari orangtuanya dan karib kerabatnya, terlepas dari jumlahharan yang yang telah ditentukan .yang mengemukakanbahwa bagian masing-masing ahli waris ditentukan.

4. Asas Keadilan Berimbangadalahkeseimbangan antara antara hak dengan kewajiban dan keseimbangan antara yang diperoleh dengan kebutuhan dan kegunaan. Dengan perkataan lain dapat dikemukakan bahwa faktor jenis

\footnotetext{
2004), hal.19.

${ }^{6}$ Amir Syarifuddin, Hukum Kewarisan Islam, (Jakarta, Prenada Media Tahun,
} 
kelamin tidak menentukan dalam hak kewarisan.

5. Kewarisan Akibat Kematiana dalah Hukum waris Islam memandang bahwa terjadinya peralihan harta hanya semata-mata karena adanyakematian. Dengan perkataan lain harta seseorang tidakdapat beralih apabila belum ada kematian. Apabila pewaris masih hidup maka peralihan harta tidak dapat dilakukan dengan pewarisan.

Catatan dalam kewarisan agama Islam salah satu syarat menjadi pewaris adalah orang yang seagama. Jadi kalau ada ahli waris yang mempunyai agama berbeda maka, akan menjadi penghalang dalam kedudukan kewarisan dalam Islam. Selain itu bagi ahli waris yang dahulunya mempunyai agama Islam akan tetapi dia menjadi murtad (keluar dari agama Islam) maka dalam Islam juga akan menjadi penghalang menjadi pewaris.

Adapun yang dimaksud sebab hilangnya hak kewarisan adalah halhal yang menggugurkan hak ahliwaris untuk mendapatkan harta warisan dari pewaris. Ada beberapa sebab yang mengakibatkan ahli waris kehilanganhaknya yaitu:

1. Perbudakan adalah Seorang yang berstatus sebagai budak tidaklah mempunyai hak untuk mewarisi sekalipun dari saudaranya. Sebab segala sesuatu yang dimiliki budakmenjadi milik tuannya juga.

2. Perbedaan Agama adalah keyakinan yang dianut antara ahli waris dan muaris (orang yang mewarisi) ini menjadi penyebab hilangnya hak kewarisan se bagaimana ditegaskan dalam hadist Rasulullah dari Usama bin Zaid, diriwayatkan oleh Bukhari, Muslim, Abu Daud, At-Tirmizi dan Ibn Majah. Yang telah disebutkan bahwa seorang muslim tidak bisa menerima warisan dari yang bukan muslim. ${ }^{7}$ Dari hadist tersebut dapat diketahui bahwa hubungan antara kerabat yang berbeda Agama dalam kehidupan sehari-hari hanya nenyangkut hubungan sosial saja.

3. Pembunuhan

4. Berlainan Negara

5.Murtad adalah Adapun yang dimaksud Murtad ialah orang yang keluar dari AgamaIslam, dan tidak dapat menerima harta pusaka dari keluarganya yang muslim. Begitu pula sebaliknya.

Dengan demikian kedudukan ahli waris non muslim (Agama Budha) terhadap harta warisan pewaris ditinjau dari hukum Islam, akan hilang kedudukannya dalam menjadi pewaris, selain itu jika seseorang menjadi murtad maka kedudukannya akan hilang dengan sendirinya secara otomatis karena dalam agama Islam orang yang non muslim dan orang yang murtad tidak berhak dalam kewarisan agama Islam. Dengan kata lain untuk

${ }^{7}$ Muhammad Muslih, Fiqih, Bogor, Yudhistira, tahun 2007, hal. 126. 
mendapatkan kedudukan kewarisan dalam Islam harus yang seagama, beda agama tidak dibenarkan. Akan tetapi ini pernah terjadi bertentangan dengan putusan pengadilan yang memperbolehkan orang non muslim mendapat warisan seperti kasus di bawah ini.

Putusan Mahkamah Agung Nomor: 368 K/AG/1995 dinyatakan bahwa ahli waris non muslim mendapatkan bagian dari harta peninggalan pewaris muslim berdasarkan wasiat wajibah sebesar bagian ahli waris anak perempuan muslim yaitu $1 / 9$ bagian, dalam putusan ini ahli waris non muslim tidak dinyatakan sebagai ahli waris, dan Putusan Mahkamah Agung Nomor : $51 \mathrm{~K} / \mathrm{AG} / 1999$ bahwa ahli waris non muslim tidak dinyatakan sebagai ahli waris dan mendapatkan harta warisan berdasarkan wasiat wajibah yaitu sebesar 1/3 bagian, dalam putusan ini ahli waris non muslim tidak dinyatakan sebagai ahli waris, namun mendapatkan harta warisan dari pewaris muslim.

Dua putusan tersebut mendapat penentangan serta menjadi putusan yang kontroversi bagi umat Islam, karena keputusan tersebut didalilkan bertentangan dengan syari'at AgamaIslam.

\section{Kedudukan Ahli Waris Non Muslim Terhadap Harta Warisan Pewaris Ditinjau Dari Ajaran Agama Budha}

Kedudukan ahli waris dalam AgamaBudha adalah menggunakan sistem hukum kewarisan Perdata Barat (BW) yang mana dalam hukum perdata (BW) yang berlaku di Indonesia berdasarkan asas konkordansi dan melalui penyesuaian seperlunya dengan keadaan Hindia Belanda (Indonesia) kemudian diberlakukan di Indonesia, Termasuk didalamnya hukum kewarisan Hukum Perdata Barat (BW), khususnya hukum kewarisannya.Kedudukan ahli waris dalam ajaran agama Budha tidaklah terlalu dipikirkan karena kedudukan dalam Budha hanyalah pilihan dan harta warisan harus disedekahkan kembali buat almarhum agar dia (almarhum) terlahir kembali dengan kehidupan yang lebih baik dengan harapan hidup dalam alam Brahma.

Landasan yang digunakan dalam waris Budha adalah hukum yang ada di Kitab Tripitka yang dalam suttanya sang Budha hanya mewarisi Dhamma bukan materi keduwian. Namun sebelum ada hukum kewarisan secara nasional dan berlaku menyeluruh bagi rakyat Indonesia untuk sementara hukum kewarisan Perdata Barat (BW) masih diperlakukan, demi untuk menghindari kekosongan hukum, meskipun pihak pemerintah dan Dewan Perwakilan Rakyat sebagai legislator menyadarinya, tetapi belum mampu membuat hukum kewarisan Nasional sebagai mana hukum perkawinan dalam Undang-Undang Nomor 1 Tahun 1974 tentang Perkawinan. 
Kalau kita analisis dari Kedudukan ahli waris dalam AgamaBudha adalah menggunakan Sistem Hukum Kewarisan Perdata Barat (BW). Hal ini tertuang dalam pasal Pasal $584 \mathrm{KUH}$ Perdata menyangkut hak waris sebagai salah satu cara untuk memperoleh hak kebendaan, oleh karenanya ditempatkan dalamBuku Ke-II KUH Perdata (tentang benda).Menurut Staatsblad 1925 Nomor 415 jo yang telah diubah ditambah dan sebagainya terakhir dengan S. 1929 No. 221 Pasal 131 jo Pasal 163, hukum kewarisan yang diatur dalam KUH Perdata tersebut diberlakukan bagi orang-orang Eropa dan mereka yang dipersamakan dengan orang-orang Eropa tersebut. Dengan Staatsblad 1917 No. 129 jo Staatsblad 1924 No. 557 hukum kewarisan dalam KUH Perdata diberlakukan bagi orang-orang Timur Asing Tionghoa. Dan berdasarkan Staatsblad 1917 No.12, tentang penundukan diri terhadap hukum Eropa, maka bagi orang-orang Indonesia dimungkinkan pula menggunakan hukum kewarisan yang tertuang dalam KUH Perdata. ${ }^{8}$

Sekarang ini Staatsblad tersebut tidak berlaku lagi setelah adanya UU RI1945 yang tidak mengenal penggolongan penduduk Indonesia. Penggolongan yang sekarang dikenal yaitu Warga Negara Indonesia dan Warga Negara Asing. Menurut KUH Perdata, ada dua cara untuk mendapatkan warisan, yaitu: ahliwaris menurut ketentuan undang-undang, dan ahli waris karena ditunjuk dalamsurat wasiat (testamen). Cara yang pertama dinamakan mewarisi menurut undang-undang atau "ab intestato", sedangkan cara yang kedua dinamakan mewarisisecara "testamentair". 9

Kedudukan kewarisan dalam Ajaran Buddha kalau kita analisa secara garis besar hukum kewarisan Barat (BW), yang disesuaikan dengan asas-asas dalam hukum KUH Perdata dengan tidak mengesampingkan hukum adat dan penghalang dalam mewarisi maka, dapat di lihat perbedaannya kedudukan ahli waris yang dikaitkan dengan pasal $830 \mathrm{KUH}$ Perdata yaitu :

1) Asas Individual adalah yang menjadi ahli waris adalah perorangan (secara pribadi) bukan kelompok ahli waris dan bukan klan, suku atau keluarga. Hal ini dapat kita lihat dalam Pasal 832 jo 852 yang menentukan bahwa yang berhak menerima warisan adalah suami atau istri yang hidup terlama, anak beserta keturunannnya.

2) Asas Bilateral artinya bahwa seseorang tidak hanya mewaris dari bapak saja tetapi juga sebaliknya dari ibu, demikian juga saudara laki-laki mewaris dari saudara laki-lakinya, maupun saudara perempuannya, hal

${ }^{8}$ R. Subekti dan R. Tjitrosudibio, Kitab Undang-Undang Hukum Pedata, (Jakarta: PradnyaParamita, 2006), hal. 1.

${ }^{9}$ Idris Ramulyo, Perbandingan Pelaksanaan Hukum Kewarisan Islam Dengan KewarisanMenurut Kitab Undang-Undang Hukum Perdata, (Jakarta: Sinar Grafika, 2000), hal. 72-73. 
ini dapat dilihat dalam Pasal 850, 853 dan 856 yang mengatur bila anakanak dan keturunannya serta suami atau istri yang hidup terlama tidak ada lagi makna harta peninggalan dari si-pewaris diwarisi oleh ibu dan bapak serta saudara baik laki-laki maupun saudara perempuan.

3) Asas Penderajatan artinya ahli waris yang derajatnya dekat dengan sipewaris menutup ahli waris yang lebih jauh derajatnya, maka untuk mempermudah perhitungan diadakan penggolongan-pengolongan ahli waris.

Dengan demikian penulis dapat menyimpulkan bahwa kedudukan ahli waris menurut agama Budha harus berlandaskan kitab Tripitaka dan Suttanya yang didalamnya tidak menentukan tentang kedudukan kewarisan dalam kewarisan akan tetapi kewarisan dalam Dhamma. Hukum yang dijadikan landasan dalam kewarisan adalah hukum KUH Perdata dalam menentukan kedudukan serta menentukan siapa yang berhak menjadi ahliwaris bagi keluarga yang ingin menetukan kedudukan kewarisan karena dalam budha itu hanya merupakan suatu pilihan bukan suatu ketetapan.

Kalau penulis kaitkan dengan Teori kepastian hukum kedudukan ahli waris non muslim menurut agama Budha dan agama Islam harus mengandung tiga unsur yaitu kepastian hukum, kemanfaatan, dan keadilan, baik hukum waris Islam maupun hukum ajaran Budha dalam menetukan kedudukan ahli waris harus sesuai dengan ketiga unsur tersebut dan ketiga unsur tersebut harus ada kompromi, proporsional seimbang sehingga tidak menimbulkan sengketa di belakang hari nanti .

Dengan kata lain untuk menentukan kedudukan non muslim menurut pandangan agama Budha yang selaras dengan KUH Perdata yaitu ada dua cara untuk mendapatkan warisan, yaitu: ahliwaris menurut ketentuan undang-undang, dan ahli waris karena ditunjuk dalamsurat wasiat (testamen). Cara yang pertama dinamakan mewarisi menurut undangundang atau "ab intestato", sedangkan cara yang kedua dinamakan mewarisisecara "testamentair".

\section{Sistem Dan Sumber Hukum Kewarisan Menurut Ajaran Agama Budha Dan Menurut Hukum Islam}

\section{Sistem Pembagian Harta Waris Menurut AjaranAgamaBudha}

Menurut Bhante Khantidharo Mahathera mengatakan bahwa umat Budha haruslah berpengangan pada Ajaran yang telah diwariskan sang Budha yang salah satu suttanya yaitu Dhammadāyāda Sutta menyatakan bahwa "DEMIKIANLAH YANG KUDENGAR. Pada suatu ketika Sang Bhagavā sedang menetap di Sāvatthī di Hutan Jeta, Taman Anāthapiṇụika. Di sana Beliau memanggil para bhikkhu: "Para bhikkhu."51 - "Yang 
Mulia," mereka menjawab. Sang Bhagavā berkata sebagai berikut: "Para bhikkhu, jadilah pewarisKu dalam Dhamma, bukan pewarisKu dalam benda-benda materi. Demi belas kasihKu kepada kalian Aku berpikir: 'Bagaimanakah agar para siswaKu dapat menjadi pewarisKu dalam Dhamma, bukan pewarisKu dalam benda-benda materi?' Jika kalian menjadi pewarisKu dalam benda-benda materi, bukan menjadi pewarisKu dalam Dhamma, maka kalian akan dicela sebagai berikut: 'Para siswa Sang Guru hidup sebagai pewarisNya dalam benda-benda materi, bukan sebagai pewaris dalam Dhamma'; dan Aku akan dicela sebagai berikut: 'Para siswa Sang Guru hidup sebagai pewarisNya dalam benda-benda materi, bukan sebagai pewarisNya dalam Dhamma.' "Jika kalian menjadi pewarisKu dalam Dhamma, bukan pewarisKu dalam benda-benda materi, maka kalian tidak akan dicela (sebagaimana akan dikatakan): 'Para siswa Sang Guru hidup sebagai pewarisNya dalam Dhamma, bukan sebagai pewarisNya dalam benda-benda materi'; dan Aku tidak akan dicela (sebagaimana akan dikatakan).

Dari apa yang dijelaskan oleh bhante tersebut penulis dapat ditarik suatu kesimpulan bahwa dalam ajaran Budha tentang warisan yang dimaksud adalah bukanlah materi akan tetapi adalah dhamma. Selain itu bhante Khantidharo Mahathera menambahkan bahwa kebahagiaan ini bukan hanya materi akan tetapi, bagaimana kita hidup dengan bahagia harus melaksanakan pancasila lima dan jalan mulia yang berunsur delapan.

Selain itu sang bhante Khantidharo Mahathera menerangkan tentang jalan mulia yang berunsur delapan. Menurut beliau itu terdapat dapat suttanya yaitu sutta ke 117 Mahācattārisaka Sutta: Sang Buddhamendefinisikan faktor-faktor Jalan Mulia Berunsur Delapandan menjelaskan hubungannya satu sama lain. Dalam Dhammacakkappavattana Sutta; Samyutta Nikaya 56.11 \{S 5.420\}, Guru Buddha mengajarkan Empat Kebenaran Ariya kepada Lima Bhikkhu Pertama (Panca Vaggiya Bhikkhu), yang didalamnya terdapat Jalan yang Menuju Terhentinya Dukkha. Jalan itu disebut dengan Jalan Mulia Berunsur Delapan (Ariya Atthangiko Magga). Di dalam Jalan ini mengandung unsur sila (kemoralan), samadhi (konsentrasi), dan panna (kebijaksanaan)

Jalan Mulia Berunsur Delapan dijabarkan sebagai berikut:

1. Pengertian Benar (Sammã Ditthi)

2. Pikiran Benar (Sammã Sankappa)

3. Ucapan Benar (Sammã Vãca).

4. Perbuatan Benar (Sammã Kammantã)

5. Penghidupan Benar (Sammã Ãjiva)

6. Usaha Benar (Sammã Vãyama)

7. Perhatian Benar (Sammã Sati) 


\section{Konsentrasi Benar (Sammã Samãdhi)}

Dari pendapat dan hasil wawancara dengan Bhante Khantidharo Mahathera sudah jelas bahwa dalam mencari nafkah untuk memenuhi kebutuhan hidup itu tidak di larang akan tetapi harus dengan cara yang benar.

Pembagian harta warisan mereka menggunakan cara kekeluargaan. Kebanyakan pembagian harta warisan sudah ditentukan bagiannya masingmasing oleh orang tua. Pihak anak selaku ahli waris langsung menerima begitu saja tanpa adanya protes, walaupun terkadang jumlah yang dibagikan tidak sama. Selain itu beliau juga menambahkan bahwa pembagian harta warisan didalam keluarganya si pewaris lebih mengutamakan anak pertama dan yang bertempat tinggal terdekat dari si pewaris. Hal ini dibenarkan oleh bapak wakimin yang merupakan salah satu setaf dari STAB. Menyatakan bahwa pembagian warisan tergantung orang tua akan tetapi anak yang sholeh (baik) akan mendapat kepercayaan dari sebagai ahli waris yang akan menjalani "Pati dana " yaitu harta warisan akan dikembalikan kepada Almarhum dengan cara memberikan sedekah kepada yang membutuhkan karena manusia yang sudah meninggal akan dilahirkan kembali dengan yang lebih baik yaitu alam brahma alamnya para dewa yang tertinggi itu yang diharapkan oleh para umat Budha.

Bhante Khantidharo Mahathera menambahkan bahwa untuk anak yang yang masuk dalam samanera dan tingkatan diatasnya akan terhalang dalam pewarisan. Karena seseorang yang telah memakai jubah berarti dia sudahtidak terikat ke dalam segala sesuatu yang bersifat keduniawian. Artinya dia sudah tidak menginginkan harta yang ada di dalam keluarganya.

Dari penjelasan di atas maka dapat ditarik suatu kesimpulan bahwa dalam ajaran Budha tidak ada sistem yang mengatur secara jelas, dan sistem pembagian tersebut dikembalikan kepada keluarga masing-masing.Karena Budha tidak mengajarkan tentang keharisan yang ada hanya kewarisan dalam bentuk Dhmama.

Selain itu anak yang memutuskan menjadi Bhiku dan samanera serta samaneri secara otomatis tidak mendapatkan suatu kewarisan.

\section{Sistem Pembagian Harta Waris Menurut Hukum Islam}

Umat muslim masyarakatnya sangat patuh dan taat pada agama, bisa dikatakan bahwa rata-rata umat Islam memiliki tingkat keimanan yang baik. Akan tetapi, dilihat dari tingkatpengetahuan mereka tentang hukumwaris juga masih sangat kurang. Memang banyak masyarakat Islam yang sudah mengenal bahkan mengetahui hukum waris Islam (fara'id), tetapi padaprakteknya masih minim ditemukan masyarakat yang menggunakannya dalam pembagian harta warisan. Meskipun ada masyarakat yang 
menerapkan fara'id ke dalam pembagian harta warisan maka pelaksanaanya tidak murni sepenuhnya menggunakan fara'id.

Ilmu faraid dalam agama Islam sudah diundangkan dalam KHI yang mana dalam pasal 172 yang menentukan tentang kewarisan yang menyatakan sebagai berikut:

1. Ahli waris, menurut pasal $172 \mathrm{KHI}$ yang disebut ahli waris-ahli waris dipandang beragama Islam apabila diketahui dari kartu identitas atau pengakuan atau amalan atau kesaksian, sedangkan bagi bayi yangbaru lahir atau anak yang belum dewasa, beragama menurut ayahnya atau lingkungannya.

2. Kelompok Ahli Waris, adapun mengenai kelompok ahli waris ditentukan pada Pasal 174 yaitu kelompok-kelompok ahli waris terdiri dari: Menurut hubungan darah antara lain :

a) Golongan laki-laki terdiri dari: ayah, anaklaki-laki, saudara lakilaki,paman dankakek.

b) Golongan perempuan terdiri dari: ibu, anak perempuan, saudara perempuandari nenek.

3. Menurut hubungan perkawinan terdiri dari: duda atau janda dengan catatan apabila semua ahli waris ada, maka yang berhak mendapat warisan hanya: anak, ayah, ibu, janda atau duda.

4. Besarnya Bagian Adapun mengenai besarnya bagian dalam Pasal 176 dijelaskan bahwa Anak perempuan bila hanya seorang ia mendapat separoh bagian, bila dua orang atau lebih mereka bersama-sama mendapat dua pertiga bagian, dan apabila anak perempuan bersama-sama dengan anak laki-laki, maka bagian anak laki-laki adalah dua berbanding satu dengan anak perempuan.

Selanjutnya pada Pasal 177 mengenai bagian yang didapat ayah Ayah mendapat sepertiga bagian bila pewaris tidak meninggalkan anak, bila ada anak, ayah mendapat seperenam bagian. Dan pada Pada Pasal 178 dinyatakan bahwa :a) Ibu mendapat seperenam bagian bila ada anak atau dua saudara atau lebih. Bila tidak ada anak atau dua orang saudara atau lebih, maka iamendapat sepertiga bagianb). Ibu mendapat sepertiga bagian dari sisa sesudahdiambil oleh janda atau duda bila bersama-sama dengan ayah.

Dari uraian diatas penulis dapat menimpulkan bahwa sistem pembagian waris dalam masyarakat yang beragama Islam ada empat pilihan dalam pembagiannya 1) hukum Islam faroid 2) dalam hukum Islam KHI dan dalam penyelesain masalah waris mereka mengedepankan penyelesaian melalui musyawarah mufakat dan langkah terahir adalah ke pengadilan. 3) menggunakan hukum ijtihat para ulama' 4). Hukum adat akan tetapi harus ada kesepakatan antar ahli waris sehingga tidak terjadi sengketa dan yang ke 
empat ini harus mendapatkan persetujuan dan kesepakatan dari semua ahli waris sehingga tidak terjadi sengketa dan perpecahan dalam keluarga.

\section{KESIMPULAN}

Dalam pembagian waris baik menurut Agama Budha maupun Agama Islam masih banyak menggunakan hukum adat atau hukum yang berlaku di masyarakat, meskipun banyak pilihan atau alternatif hukum dalam pembagian waris yang dapat digunakan antara lain, dalam Islam menggunakan 1) hukum faroid/hukum Islam 2) KHI dan 3) menggunakan KUH Perdata se 4) hukum adat (harus ada kesepakatan antara ahli waris terlebih dahulu sehingga sengketa dapat dihindari). Sedangkan dalam ajaran Budha hukum yang digunakan dalam pembagian waris adalah Hukum adat dan KUH Perdata. Sedangkan yang menerima warisan dalam agama Islam semuanya ahli waris bisa menerima asalkan tidak terhalang (alasan tidak bisa menerima waris) sedangkan dalam agama Budha tidak semua ahli waris karena jika dalam keluarga tersebut (ahli waris) ada yang memutuskan untuk menjadi samanera atau samaneri dan bhikku maka secara otomatis dia tidak akan bisa menerima warisan.

Kedudukan ahli waris non muslim (penganut agama Budha) terhadap harta warisan pewaris ditinjau dari ajaran agama Budha dan hukum Islam. Kedudukan tentang warisan menurut agama Budha harus berlandaskan kitab Tripitaka dan Suttanya dan hukum yang dijadikan landasan adalah hukum KUH Perdata yang mana kedudukannya waris bisa dikasihkan ke siapa saja. Sedangkan dalam Islam kedudukan waris harus sesuai dengan al-quran dan As-Sunnah yang mana warisan tidak bisa dibagikan kepada orang lain hanya khusus bagi yang berhak mendapatkan warisan tersebut.

\section{DAFTAR PUSTAKA}

Amir Syarifuddin, 2004, Hukum Kewarisan Islam, Jakarta: Prenada Media Tahun.

Idris Ramulyo, 2000,Perbandingan Pelaksanaan Hukum Kewarisan Islam Dengan KewarisanMenurut Kitab Undang-Undang Hukum Perdata, Jakarta: Sinar Grafika.

Moh. Muhibbin dan Abdul Wahid,2009, Hukum Kewarisan Islam sebagai Pembaruan Hukum Positif di Indonesia, Jakarta: Sinar Grafika.

Muhammad Muslih,2007, Fiqih, Bogor: Yudhistira.

M. O’C. Walshe Willy Liu 2010, Ajaran Buddha Dan Kematian, Cetakan Pertama, Yokyakarta: Vidyāsenā Production. 
R. Subekti dan R. Tjitrosudibio,2006, Kitab Undang-Undang Hukum Pedata, Jakarta: Pradnya Paramita.

Soerjono Soekanto dan Sri Mamuji, 2003, Penelitian Hukum Normatif Suatu Tinjauan Singkat, Jakarta: RajaGrafindo Persada.

Sutrisno Hadi, 2000, "Metodologi Researh Jilid 1", Yogyakarta.

Vollmar, 1989, Pengantar Studi Hukum Perdata Jilid I, diterjemahkan oleh I.S.Adiwimarta, Jakarta: PT.Rajawali Pers. 